\title{
Seeing and Hearing the Other: A Jewish Israeli Teacher Grapples with Arab Students' Underachievement and the Exclusion of Their Voices
}

\author{
by Tamar Hager
}

\section{Introduction}

This paper begins with feelings of frustration and anger. It has grown out of my distressing continuous encounter-as a feminist Jewish teacher in a college in northern Israel-with the glaring examples of inequality and structural discrimination experienced by Arab students in Israeli academia. ${ }^{1}$ I thought that narrating and analyzing my vulnerability, despair and rage as well as Arab students' feelings of alienation might help us to better understand social and political obstacles, while constructing ways to better overcome these educational impediments.

Following bell hooks (1994) and Sarah Ahmed (2004) I consider our (mine and theirs) emotions as significant information as to the power structure reflected in my classrooms-the structure that assigns Arab students an inferior position in Israeli institutions of higher education. Ahmed suggests reading the relations between "affect and structure, or between emotion and politics in a way that undoes the separation of the individual from others" (2004, p.174). This reading which exposes the connection between me, the Jewish teacher, and each of my Arab students, enables me to challenge the common perspective which ascribes minority students' difficulties and estrangement to their educational and cultural deficiencies (Essed, 1999, p. 221). If our emotions are read as evidence of our political adherence, the students' feelings of estrangement as well as my frustration and helplessness indicate the deficiency of our present educational exchange and the need to transform the micro-politics of the classroom.

\section{The alienated behavior of these students which is frequently understood by teachers as their disregard, lack of interest and uncaring attitude towards the course provokes feelings of frustration and rage, often mixed with guilt.}

Striving to comprehend the complex micro-politics which evoke my negative feelings and theirs, I have initially chosen to narrate what happens in class, hoping to clarify why our exchange induces my anger. I focus on my own experience, yet I believe that similar interactions occur in other classes in academia where teachers cope with minority students who undergo institutional discrimination. Subsequently the paper undermines teachers' justification for directing their/our anger towards minority students by analyzing the reasons for the students' feelings of alienation.

The next part of the paper tells the story of my resistance to this prevailing social and political structure. Adopting feminist critical pedagogy in my course Representing Disability in Literature and the Cinema, I have defied "the traditional hierarchical relationship between teacher and taught" and have created a space for my Arab students to overcome "the internalized barriers 
created by the dominant group's negative evaluations of them" (Morley, 1998, p.16). The process of empowerment and the subsequent educational transformative and liberating exchange has enabled all participants to grant Arabs' transparent and excluded knowledge a significant social, cultural and political place, thus creating new and more culturally sensitive knowledge. Confronting the empowering effects of this method, I conclude my paper by suggesting some explanations as to the rarity of critical feminist pedagogies in Israeli academia.

\section{Emotional Circle: Alienation, Frustration and Anger}

Entering the first class of a new semester, I always notice her/him/them. ${ }^{2}$ He sits in the last row and stares at me, but her stare never convinces me that she understands what I am talking about. Throughout the semester he tends to disappear for several meetings and reappear again in silence in the last row, rarely participating in the class discussion. Sometimes she leaves the classroom to use the phone and returns after half an hour or fails to return altogether. He rarely reads the assigned texts or summarizes lectures. Her grades are lower than average. Their Hebrew language proficiency is poor, and it is hard to comprehend what they are saying or writing. In the worst cases, she hands in assignments she has copied from classmates or from an internet site, and more often than not, he is caught at this, after failing to notice (chiefly because she does not know Hebrew well enough) and delete telltale signs identifying the original paper. These students' profiles, I imagine, are known to many teachers across national, ethnic, class and gender boundaries. In Tel Hai College (and in most other higher education institutions in Israel), however, a significant number of them are Arabs, citizens of Israel. ${ }^{3}$

The alienated behavior of these students which is frequently understood by teachers as their disregard, lack of interest and uncaring attitude towards the course provokes feelings of frustration and rage, often mixed with guilt. I try without much success to encourage them to ask for my help and that of others. Sometimes I help them to apply for a mentoring program which was constructed to meet their needs. ${ }^{4}$ At other times I ask for an excelling student in class to help them in their coursework. I feel sorry for them. I tend to give them higher grades than they have earned, sometimes as atonement for being unable to help them, sometimes as a sign of recognition of their difficulties: Hebrew is not their first language; Jewish culture is not their culture. Israel is hardly their country, since state institutions by implicit policy discriminate against them, situating them as second-class citizens.

Too often my frustration turns into anger. Recognizing her difficulties, I warn him that missing classes will lead to failing the course but, as I sadly expect, she goes on missing classes. Well, I think, he does not take responsibility, just adding another failure to his expanding list. Serves them right, I think; why should I show any consideration if they never listen or do what I say? At this point I am unaware that my arrogance and my rage are holy and self-righteous and lead us, me, her, and him nowhere, on our shared journey towards higher education.

Reflecting on my instinctive resentment, I realize that I, despite myself, too frequently fall into the trap of new racism, explaining discrimination as a problem of the victim, a result of his-her cultural mentality, personal or collective traits (Hopkins et al., 2008; Balibar, 2008). This is my and others' "efficient way" to create explanations which justify social gaps without having to take responsibility and use educational methods to change class climate.

In the face of this disagreeable and disturbing picture of myself, I remember something I know and tend to forget in the daily wearing routine of teaching, that Arab citizens of Israel undergo institutional discrimination in Israeli academia in general and in Tel Hai College in particular. This awareness does not diminish my helplessness and frustration, yet it ends my unjustified rage.

\section{Political Climate: Arabs in Tel Hai College}

Tel Hai College is located in the northern periphery of Israel, where $53 \%$ of the inhabitants are Arab citizens of Israel (Central Bureau of Statistics 2011). As in most academic institutions in the country, however, here too, faculty and students include a small minority of Arabs, far smaller than the $20 \%$ Arab minority in Israel's population. In 2011, for instance, Arabs accounted for $13 \%$ of the college student body and $8.3 \%$ of its faculty. ${ }^{5}$

The college, like most institutions of higher education in Israel, is primarily a Jewish college. The spoken and written language is Hebrew, which is the second and sometimes the third language of the Arab students, who therefore face a disadvantage in reading and writing tasks in comparison to their Jewish peers.

Furthermore, the Arab public school system inside Israel, which most Arab students have attended, though legally obliged to provide a level of education equal to that offered to Jewish citizens, is in fact inferior, on average, to the Jewish public school system due, in part, to the unequal budgets and resources allocated by Israel's government. This often creates gaps in knowledge in a range of subjects (Golan-Agnon, 2004; Jabareen and Agbaria, 2011; Arar, 2012). Arab students from Israel also find it more difficult than their Jewish peers to meet the demands of an academic system that requires critical discourse, as Arab schools tend to allow less room for expressing opinions and encourage more passive learning (Al Haj, 1996; Barak et al., 2000). Therefore, many Arab students are at a disadvantage when they reach Tel Hai College, especially relative to their Jewish counterparts. Many of them lack both the cultural capital (Bourdieu, 1977, 1986, 2005; Olneck, 2000) and the type of academic skills required for coping with Western-influenced Israeli culture, making it difficult for them to match the achievements of their Jewish peers. In addition, the socioeconomic status of Arab students from Israel is generally lower than that of their Jewish classmates with the gap increasing all the more in college due to 
discrimination against Arabs in the job market and the limited availability of scholarships for Arab students (AlHaj, 2001, 2003; Dagan-Buzaglo, 2007; Arar and Mustafa, 2011).

Arab students from Israel are also assigned a cultural minority position. As in other higher education institutions in Israel, the hidden curriculum of the college-the "unstated norms, values and beliefs embedded in and transmitted to students through their underlying rules that structure the routine and social relationships"-is controlled by the Jewish dominant group (Giroux, 1983, p.47; Doyle and Singh, 2006). For example, Jewish culture, customs and holidays dictate the structure of the school year and the academic content, while Arab culture is virtually nonexistent within the organizational space (although nonJewish students are permitted absences on Muslim, Christian and Druze holidays). Arabic is spoken and heard principally in the informal margins of institutional space: in the hallways, in the cafeteria and on the lawns.

Additionally, every outbreak of violence between Israel and its non-citizen subjects in the West Bank, or the Gaza Strip, or its Arab neighbors in Lebanon or Syria affect campus life and relationships, heightening tensions and anger among Arabs and Jews, silencing Arab students' voices and opinions which frequently do not go hand in hand with the Jewish consensus.

In this reality, it is difficult for most of the Arab students to fulfill the expectations of the predominantly Jewish academic system. As a result, their achievements are significantly lower than those of their Jewish peers (AlHaj, 2001, 2003; Hager et. al, 2011; Arar and Mustafa, 2011).

The analysis and recognition of both the formal and hidden curricula enabled me to better understand the political, social, educational and institutional obstacles awaiting my Arab students. This challenged me to transform my teaching and thus to change the micropolitics of the classroom (Denzin, 2007; hooks, 1994).

Henry Giroux asserts that "while the hidden curriculum cannot be entirely eliminated, its structural properties can be identified and modified" thus enabling the teacher to develop new pedagogical methods (Giroux, 1988, p.51). These methods, which Giroux and others identify as critical pedagogy, may partially and temporarily transform the power relations in class and may develop critical and political consciousness among participants, students and teacher.

However, critical pedagogy, claims Norman Denzin, "requires citizens and citizen-scholars committed to taking risks, persons willing to act in situations where the outcome cannot be predicted in advance" (Denzin, 2007, p.139). bell hooks has accurately acknowledged the reluctance of many teachers "to see the classroom change, to allow for shifts in relations between students" between students and me their teacher (hooks, 1994, p.30). hooks and Denzin remind me that using methods of critical pedagogy transforms the educational power structure and if I aspire that my class will contain "persons jointly working together to develop new lines of action, new stories, new narratives in a collaborative effort," my authority as the class teacher will be threatened (Denzin, 2007, p.139). To create these changes teachers should overcome their fears, work harder, be adventurous, imaginative and spontaneous (hooks, 1994). No wonder many of them panic.

\section{Taking the lead from her story, we didn't discuss the social construction of disability, but rather the unequal distribution of resources in Israeli society, the lack of proper treatment for the Arab and the poor disabled.}

These difficulties did not deter me. Following Nancy Naples (2002), I wanted to develop "a critical feminist pedagogy that is open to self-reflexivity about the processes by which we produce knowledge for and with our students" (p.16). But how should I do it? Spontaneity and imagination are not activities you can plan. Classes vary and their needs change. How am I going to know that my reaction to my students is the proper one?

What follows is my story of some precious moments when I was able and willing to take the pedagogical and personal risk and use critical pedagogy to reverse the existing social and political power relations in the classroom. Creating space for my Arab students allowed them to voice their stories. Together, all participants transformed the educational site by collaborating to make room for new stories and new knowledge.

\section{Changing the Climate: Seeing and Hearing the Other}

My class Representing Disability in Literature and the Cinema was crowded; 50 students filled the room, mostly Jews. I noticed three Arab women students sitting in the last row. They held their bags on their knees, as if ready to get up and leave. There was no evidence of notebooks or sheets of writing paper. "According to various social theories, disability is a social construction," I stated. "Different societies grasp disability differently. In some societies disabled people are excluded and committed to special institutions while in others they are held as cherished members of the community, cared for by family and neighbors." I leafed through my papers looking hurriedly at the usual examples for attitudes towards disabled people in various societies and cultures that I had prepared in advance. When I raised my eyes to continue, I saw the three students staring at me. It was then that I realized what I should do. Maybe something new would happen if I took my chances and related to the Arab community, though I knew nothing of its attitude towards disability. Maybe these three students in the last row would give us fresh examples, benefiting us all and acquiring space and voice. Maybe next time they would actually put their bags on the floor and plan on staying in class. 
Pushing my luck, I said: "In traditional societies like the rural Palestinian society...." The three students in the last row were listening, their bags still on their knees, now looking at me intently rather than staring numbly. "Who lives in a Palestinian village and can tell us how the disabled are treated?" I asked. The students, mostly Jewish, were looking backwards. Suddenly the usually silent Arab students were the center of attention, the ones whose knowledge the lecturer was seeking. One of them raised her hand. She told us slowly, in poor Hebrew, that her brother was disabled and lived at home, since her parents could not find a suitable institution for him. Good institutions are private, expensive ones and the nearest affordable public institutions have no Arab teachers. He couldn't manage with Hebrew. Even his Arabic was very

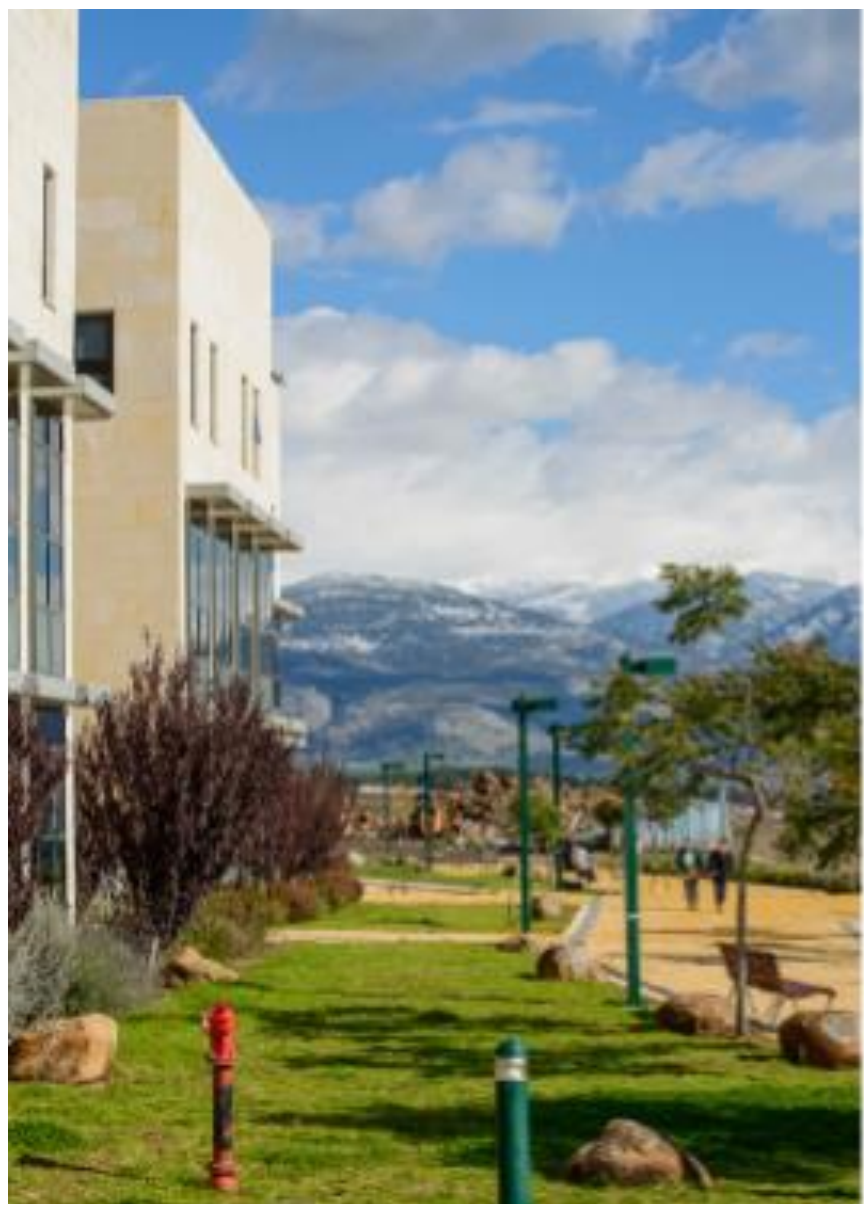

gave examples, asking for stories on disability in Arab culture. Gradually they didn't wait for my questions, but volunteered their opinions, stories and comments, laboring to use Hebrew. Their curious and intent gaze during the course sessions and their frequent participation in class discussions made me acknowledge their presence (hooks, 1994, p.8). Jane Rinehart (2002) points out that "students enter the classroom as representatives of a variety of interpretative communities . . . making communication more likely to be troublesome because translation is necessary" (p.25). I turned into a translator, constantly checking my cultural assumptions as to the prior knowledge held by my students, fairly assuming that Arabs don't usually possess the Eurocentric and Westernized cultural capital adopted by the Jewish hegemony.

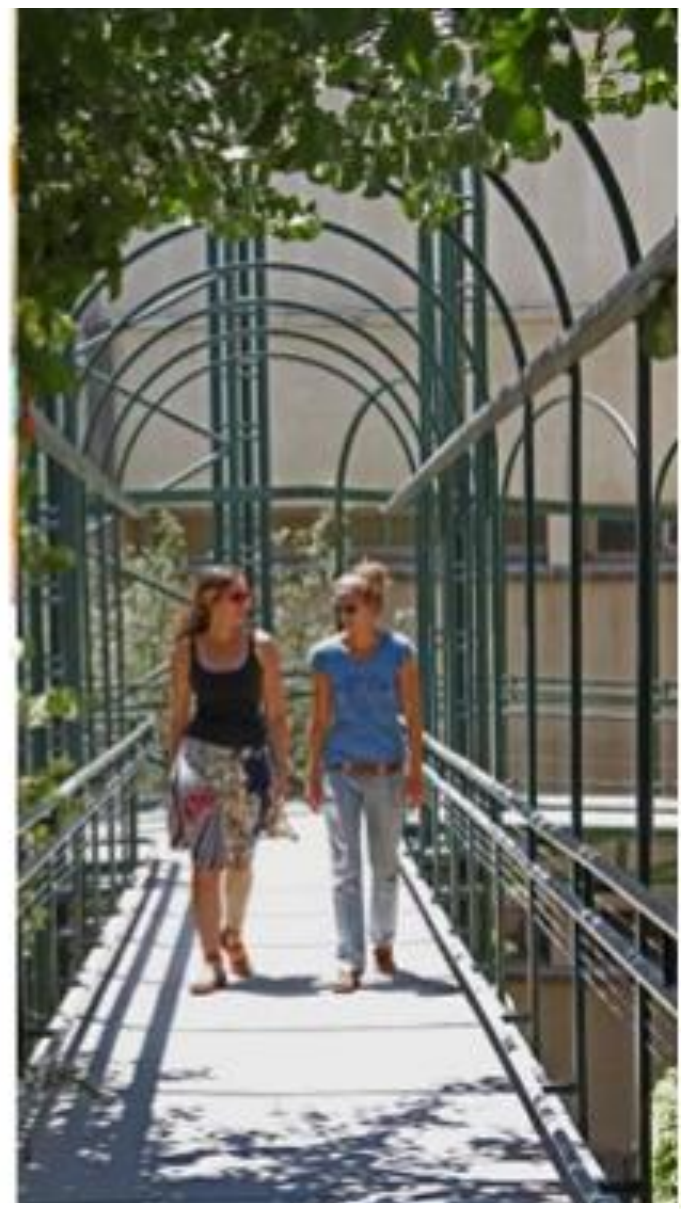

FROM TEL HAI COLLEGE WEBSITE

poor, she explained. "So who takes care of him?" I asked. "My parents and the neighbors", she answered. "But we wish it was otherwise."

Taking the lead from her story, we didn't discuss the social construction of disability, but rather the unequal distribution of resources in Israeli society, the lack of proper treatment for the Arab and the poor disabled. Another Arab student told us about a documentary film dealing with this issue and suggested screening it in class. When the lesson ended, she and her two friends were surrounded by Jewish students. I could see the smiles of the Arab students and the curiosity of the others.

During the remaining course sessions, the three students sat in the first row. I turned to them whenever I
Subsequently I fully noticed the narrowness of my literary and film corpus which, until then, had seemed to me quite broad and representative of all important trends.

\section{Changing the Climate: Transforming Oneself}

Following my Arab students, I wanted to cross cultural boundaries and examine the representations of disability in works of art created in other parts of the globe. At home I kept looking for texts from Middle East and North African countries to balance my examples, to bring new perspectives to class but also to contain the Arab students. This search made me realize how limited my corpus had 
been. I also understood that it was not only because I was oblivious to the impact of the exclusion of the Arab culture from the curricula on my individual work as a teacher, but rather because most literary and film analyses in the discipline of disabilities studies which I came across focused on Western culture.

This point became a center of discussion in one of the sessions, creating a space for one of the Arab students to express her feelings of estrangement in most of the courses she attended. "I sometimes don't understand the examples the teachers are giving and none of them is actually relevant to my life," she said. One of the Jewish students maintained that she realized during the last sessions how exclusionary the academic curriculum is. "I see clearly now," she said, "most of us have never heard the stories of the disabled or the narratives of Arab citizens of Israel and I wonder what else we don't hear, see, or know. It seems like someone is interested in concealing important knowledge from us. It is so frustrating and annoying." She was looking at me attentively as if expecting me to calm her fears of a global conspiracy. This comment became an opportunity to discuss the nature of knowledge itself. I shared with them my belief as a feminist that knowledge is always partial, exclusionary and incomplete. Relating to Louise Morley's claim that knowledge is "produced in the process of the interaction of classroom engagement," I introduced our class as a space for building knowledge together (Morley, 1998, p.16).

The opportunity to discuss these important issues came up only because I was ready to take the pedagogical risk and give space to these three young women in the first row, who were willing to share with us their different cultural perspective and stories (Denzin, 2007; hooks, 1994). Although this thought came to my mind while discussing these issues, I avoided sharing it with the students. I was afraid to embarrass the Arab students and/or put too much pressure on them, too much responsibility. I was afraid this claim would objectify them and force them "to assume the role of 'native informant" (hooks, 1994, p.43), the oriental other (Said 2000 [1979]), valuable objects of our-mine and my Jewish students'anthropological gaze. But I became silent also because at that point I had lost my pedagogical courage and felt that to focus again on the Arab students would upset the other students and might raise hostility towards me. This antagonism would leave an impact on their assessments of my course. The conventional academic lecturer in me was raising her head worrying that praising Arab students too much would be educationally inappropriate.

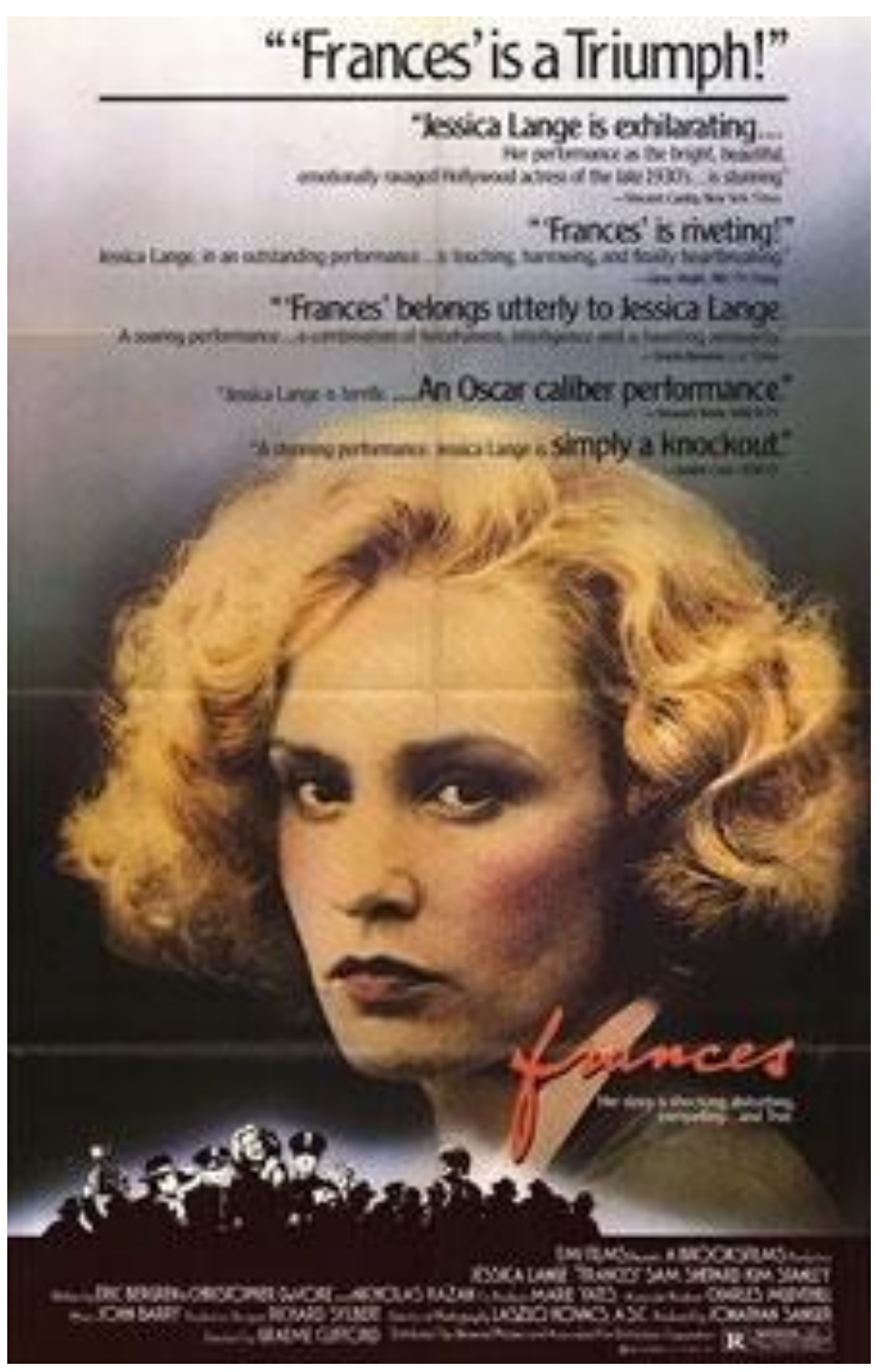

Writing my story now, I am convinced that silencing my praise was a mistake. The three Arab students deserved the full credit not only for teaching me and their Jewish peers innovative valuable information, but also for uncovering my/our ignorance. I think now that I should have risked the accusation of Orientalism, or the danger of students' criticism for the sake of thanking them publicly.

However, it seemed to me that they had, in any case, benefited from the process. They regularly attended classes, completed homework assignments. Whenever they needed help with the coursework, they turned to me or to the other students. It was clear that they took responsibility for their studies: they told stories, described movies, shared with us research dealing with disability as related to and addressed by Arabs in Israel and abroad and voiced their opinions concerning all issues discussed in class. Close to the end of the course, after seeing the movie Frances addressing the actress Frances Farmer's repeated forced hospitalizations in mental institutions, one of the Arab students submitted a short paper voluntarily.

"I am not proficient in Hebrew," she wrote. "But I tried to express my anger towards reality in this language. I hope it will be clear despite my grammatical mistakes." Providing her critical analysis of the movie, she claimed that seeing it made her acknowledge women's oppression. "It is clear to me that I am doing a subjective and not objective analysis of the story!!! This was the problem that 
led Frances to 'madness', and this is the problem of all women. We are accustomed to being sensitive and following our hearts. In this way it is easier to get hold of us. We were taught how important it is to be beautiful all the time and to take care of ourselves. This way it is easier to take advantage of us. We have turned into the most delicate creatures on Earth, who are 'really amazing' but easily broken. Many women break down."

The story of the Arab minority which they had revealed became a significant part of the course. Instead of a regular course on disability in literature and the cinema, I found myself dedicating sessions to teaching about disability in a multicultural context. However, the class gained more than the Arab social and cultural narratives of disability. Since the voices and stories in the class were culturally and socially diverse, the students learned to listen more sensitively and attentively to one another.

Reading her comment I remembered bell hooks' observation that education could be the practice of freedom if teachers and students become critical and engaged participants rather than passive consumers, connecting "our will to know with our will to become" (hooks, 1994, p.19). Here was a young Arab student who was struggling against all types of oppression in order to become.

The story of the Arab minority which they had revealed became a significant part of the course. Instead of a regular course on disability in literature and the cinema, I found myself dedicating sessions to teaching about disability in a multicultural context. However, the class gained more than the Arab social and cultural narratives of disability. Since the voices and stories in the class were culturally and socially diverse, the students learned to listen more sensitively and attentively to one another. bell hooks claims that "to listen to one another, is an exercise in recognition" (hooks, 1994, p.41). This capacity to acknowledge difference became an opportunity for each of us to question our social and cultural perspectives and norms. Consequently, the course turned into a space for challenging our perceptions of disability, of women's position, of academic freedom, of the educator's role, thus expanding our knowledge to include excluded and absent voices and stories (Morley, 1998, p.16).

\section{Endless Efforts}

My teaching to counteract in this course ended with a sense of achievement. Providing Arab students' voices and stories a central place in Israeli academia undermines the status quo which relegates Palestinian culture and history to the margins considering them frequently a threat to
Jewish hegemony. The micro-politics of this particular classroom which intentionally gave space to stories of discrimination, exclusion and oppression was transformed. Gone were Arab students' alienation and resignation as well as my feelings of helplessness and frustration.

However, outside the walls of this classroom nothing has changed. In most courses Arab students (probably the students in my courses as well) are still considered to be the underachievers, the wearisome problem, those who, without assistance, would not survive the academic system. As I claimed earlier, this perspective echoed the pervasive tendency to blame the victims. But even teachers who acknowledge Arab students' inferior position in higher education institutions have found it hard to apply radical pedagogy in class. I myself have not always found the courage and strength to resist the prevailing power structure in my teaching. I would like to conclude this paper by trying to explain why these moments of resistance are so precious and rare; why it is so hard to challenge the prevailing social and political order even when acknowledging the deficiency of the present educational exchange and the need to transform the micropolitics of the classroom.

Disrupting the existing power structure involves institutional risks. According to Elizabeth Brule, most students who are used to the established teaching methods want to know the right or correct answer and refuse to engage themselves in critical pedagogy and to question the power structure. For these students critical feminist educators, who question established norms and perspectives while refusing to provide ready answers, are considered incompetent teachers (Brule, 2004). Moreover, applying these methods could turn the classroom into "a site of conflict, tensions and sometimes ongoing hostility" (hooks, 1994, p.111). In a reality in which students' assessments of teachers' aptitude can determine a teacher's career in a neoliberal academia which seeks more and more economic efficiency, fostering feminist and antiracist perspectives is a gamble many teachers are not willing to take.

\section{Disrupting the existing power structure involves institutional risks. According to Elizabeth Brule, most students who are used to the established teaching methods want to know the right or correct answer and refuse to engage themselves in critical pedagogy and to question the power structure.}

Institutional sanctions may also await teachers who dare to question the political consensus in Israel and give voice to stories of prolonged injustice. If students complain to the management about a "straying" teacher, there is a chance that he/she will be rebuked or at least warned to be careful.

Furthermore, liberatory education involves emotional labor as Morley (1998) rightly suggests. Whenever I use 
critical feminist pedagogy in my classes I feel the strain embedded in ostensible power sharing. Much effort is invested in deciding when and how to transfer power to students and let them lead the discussion. The need to make spontaneous decisions and use my imagination is also a source of tension. And what works for one class does not necessarily work for another; thus every course forces me/us to start anew. I agree with Nancy K. Miller that "the narrative of [such] occasions is necessarily locational: it is what happens to theory in the flesh of practice, the in the social spaces of institutional life" (quoted in Feighenbaum, 2007, p. 340). As in my case, this locational process frequently involves changing the course's syllabus and investing great effort in preparing new lectures. This effort is pedagogically and intellectually worthwhile, yet it becomes a burden in the underfunded, patriarchal and hierarchical system which increases teachers' work load and publication demands (Feigenbaum, 2007, p.346). I agree with Nancy Naples (2002) when she claims that the presupposition that teachers can always interrogate hidden assumptions and limitations with their students is "a problematic assertion in the context of our institutional location within the academy, as subjects within a racist homophobic social context" (p.16).

Still, despite all these setbacks and obstacles, we cannot be easily discouraged nor should we despair. For me the intent look of the three Arab women in the first row is a reminder that changing the micro-politics of the classroom leaves its impact on all those involved. And this is definitely a good reason to continue.

\section{Notes}

1. The self-definitions of individual Arab citizens of Israel vary enormously. Some of them view themselves as Palestinians. Others do not. In Tel Hai there is also a significant group of Druze from the Golan Heights who see themselves as Syrian citizens and some of them do not hold Israeli identity cards. In view of all these issues, with much hesitation, I have chosen to apply the term Arabs or (since most students do hold Israeli identity card) Arab citizens of Israel, to the students of Tel Hai College.

\section{Works Cited}

1. Ahmed, S. (2004). The Cultural Politics of Emotion. Edinburgh: Edinburgh University Press.

2. Al-Haj, M. (1996). Education Among the Arabs in Israel: Control and Social Change. Jerusalem: The Magnes Press (Hebrew).

3. Al-Haj, M. (2001). A Report to the Sub-Committee of Planning and Budgeting Committee for Promoting High Education Among the Arab Population. Jerusalem: The Council for High Education (Hebrew).

4. Al-Haj, M. (2003). Higher education among the Arabs in Israel: Formal policy between empowerment and control. Higher Education Policy, 16, 351-368.

5. Arar K. \& Mustafa M. (2011). Access to higher education for Palestinians in Israel. Education, Business and Society:
2. My impression is that this behavior characterizes both female and male students.

3. This paper discusses teaching to counteract systemic discrimination against Arab citizens of Israel or in the case of the Druze in the Golan Heights, Arabs who live within Israel's borders. It does not engage, at all, with the question of teaching to counteract the very different, less subtle and far more blatant types of discrimination and oppression exercised against Palestinian students from the occupied territories. To the best of my knowledge, no students from the West Bank or the Gaza Strip attend or have recently attended Tel Hai College. My ongoing encounter, and therefore this paper, both focus on teaching to resist the enforced academic (and other) disadvantages and the structural discrimination exercised against students coming from and living inside the "Green Line" and in the Golan Heights.

4. The mentoring program as well as other programs was initiated by the Center of Peace and Democracy to meet Arab students' difficulties. The Center was founded in 2007 following five years of bottom-up initiative. The objective of the center has been to support Arab students and to increase the opportunity for mutual cultural exchange among Arabs and Jews (more information on the center's aims and activities: Hager and Saba, 2009 and Hager and Saba, 2013).

5. The mentoring program as well as other programs was initiated by the Center of Peace and Democracy to meet Arab students' difficulties. The Center was founded in 2007 following five years of bottom-up initiative. The objective of the center has been to support Arab students and to increase the opportunity for mutual cultural exchange among Arabs and Jews (more information on the center's aims and activities: Hager and Saba, 2009 and Hager and Saba, 2013).

Contemporary Middle Eastern Issues, 4(3), 207-228. doi $10.1108 / 17537981111159975$.

6. Arar, K. (2012). Israeli education policy since 1948 and the state of Arab education in Israel. Italian Journal of Sociology of Education, 4(1), 113-141.

7. Balibar, E. (2008). Does the new racism exist? In $Y$. Shenhav \& Y.Yona (Eds.) Racism in Israel, (416-425). Jerusalem, Tel Aviv: Van Leer Institute, Hakibbutz Hameuchad (Hebrew).

8. Barak M. Peleg R. \& Avrahami M. (2000). Scientific technological education as a focus of the renewal of the ArabDruze school in Israel. Iyunim B'khinukh (Studies in Education). 4 (2), 51-76 (Hebrew).

9. Bourdieu, P. (1986) The forms of capital. In J. Richardson (Ed.) Handbook of Theory and Research for the Sociology of Education (pp.241-258). New York, Greenwood. 
10. Bourdieu, P. (2005). The linguistic market. In Sociology in Question (pp. 121-133). Tel Aviv: Resling (Hebrew).

11. Bourdieu, P., \& Passeron J. (1977) Reproduction in Education, Society and Culture. London: Sage.

12. Brule, E. (2004). Going to the market: Neoliberalism and the social construction of the university student and an autonomous consumer. In Marilee Reimer (ed.) Inside Corporate U: Women in the Academy Speak Out (255-281). Toronto: Sumach Press.

13. Dagan-Buzaglo, N. (2007). The right to higher education in Israel: Legal and budgetary perspective. Adva Centre: Information on Equality and Social Justice in Israel http://www.adva.org (retrieved March, 13).

14. Denzin, N. (2007). The politics and ethic of performance pedagogy: Toward a pedagogy of hope. In McLaren \& Kincheloe (Eds.) Critical Pedagogy: Where Are We Now? (127142). New York: Peter Lang.

15. Doyle C. and Singh, A. (2006). Reading and Teaching Henry Giroux. New York: Peter Lang.

16. Essed, P. (1999). Ethnicity and diversity in Dutch academia. Social Identities 5(2), 211-225.

17. Feigenbaum, A. (2007). The teachable moment: Feminist pedagogy and the neoliberal classroom. Review of Education, Pedagogy and Cultural Studies. 29(4), 337-349.

18. Giroux, H. (1983). Theory and Resistance in Education: Pedagogy for the Opposition. Westport: Bergin \& Garvey.

19. Giroux, H. (1988). Teachers as Intellectuals: Towards a Critical Pedagogy of Learning. Westport: Bergin \& Garvey.

20. Golan-Agnon, D. (ed.). (2004). Inequality in Education. Tel Aviv, Babel (Hebrew)

21. Hager, T. Shamai, S. Garriba, R., Sivan, T. Saba, T. \& Shay, N. (2011). Multiculturalism on campus in the shadow of Jewish-Arab conflict: Jewish and Arab students' attitudes. In Leehue Zysberg (ed.) Student Attitudes (pp. 56-84). Hauppauge, New York: Nova Publishers.

22. Hager T. and Saba T. (2009). Changing against the grain Academy for peace in a reality of conflict. Diaspora, Indigenous and Minority Education: An International Journal, 3(3-4), 191-201.

23. Hager, T. and Saba, T. (2013). "Between Obstacles and Challenges: Could Israeli Academia Respond to the Jewish Arab Conflict?" Unpublished paper given at the conference on Racism and Anti-Racism through Education and Community Practice: An International Exchange, University of Edinburgh, Scotland UK.

24. hooks, b. (1994) Teaching to Transgress: Education as the Practice of Freedom. New York, London: Routledge.

25. Hopkins, N, Reicher S. \& Levine, M. (1997). On the Parallels between Social Cognition and the New Racism. British Journal of Social Psychology, 36, 305-329.

26. Jabareen, Y. and Agbaria A. (2011). Education on Hold: Israeli Government Policy and Civil Society Initiatives to Improve Arab Education in Israel. Dirasat: The Arab Center for Law and Policy \& The Arab Minority Rights Clinic, Faculty of Law, University of Haifa. Retrieved from http://www.dirasataclp.org/files/Report_Education\%200n\%20Hold_Jan2011.pdf.

27. Morley, L. (1998). All you need is love: Feminist pedagogy for empowerment and emotional labour in the academy. International Journal of Inclusive Education 2(1), 15-27.

28. Naples, A. N. (2002). The dynamics of critical pedagogy, Experimental learning, and Feminist praxis in women's studies. In Nancy A. Naples and Karen Bojar (eds.) Teaching Feminist

Activism: Strategies from the Field (9-21). New York, London,
New York: Routledge.

29. Olneck, M. (2000). Can multicultural education change what counts as cultural capital? American Educational Research Journal, 37(2), 317-348.

30. Rinehart, J. A. (2002). Collaborative learning, subversive teaching and activism. In Nancy A. Naples and Karen Bojar (eds.) Teaching Feminist Activism: Strategies from the Field. (22-35). New York, London, New York: Routledge.

31. Said, E. (2000). Orientalism. Translated by Atalia Zilber, Tel Aviv: Am Oved (Hebrew).

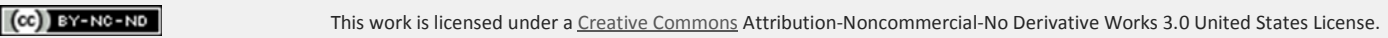

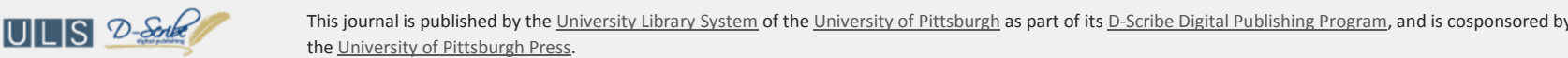

